DOI: https://doi.org/10.31933/jemsi.v3i3

Received: 9 November 2021, Revised: 17 Desember 2021, Publish: 1 Januari 2022

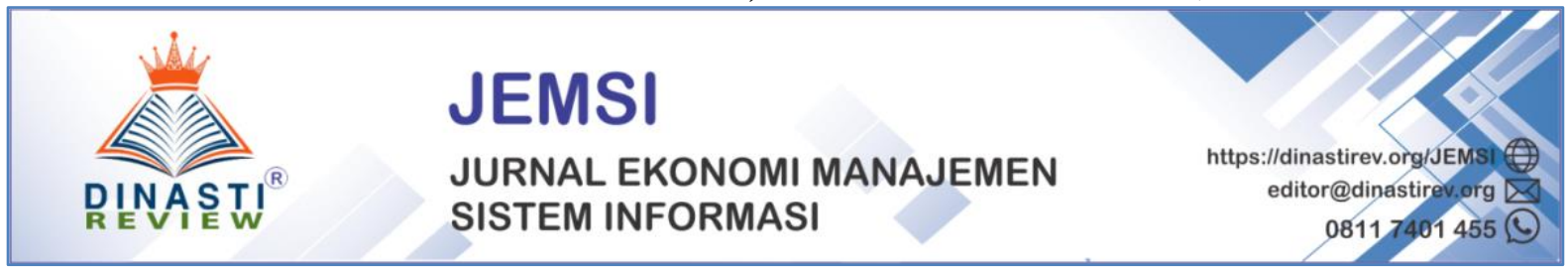

\title{
LITERATURE REVIEW DETERMINASI SISTEM INFORMASI MANAJEMEN: DATABASE, CCTV DAN BRAINWARE
}

\author{
Mega Aswiputri ${ }^{1}$ \\ ${ }^{1)}$ Mahasiswa Fakultas Ekonomi, Universitas Bhayangkara Jakarta Raya, email: \\ megaswiputri@gmail.com
}

Korespondensi Penulis: Mega Aswiputri ${ }^{1}$

\begin{abstract}
Abstrak: Sistem informasi manajemen memiliki hubungan yang erat dengan berbagai komponen dalam proses menghasilkan sistem informasi untuk memenuhi kebutuhannya. Hal ini sesuai dengan penerapan komponen tersebut, dimana informasi yang kurang akurat, kurang detail, tepat waktu dan kurang relevan akan menimbulkan kesalahan dalam proses pengambilan keputusan perusahaan. Oleh karena itu, diperlukan pemahaman yang mendalam tentang komponen dan sistem informasi manajemen, terutama database, CCTV, database dan brainware untuk menghasilkan informasi yang berharga, efektif, dan berkualitas, efektif bagi perusahaan. Tujuan penulisan artikel ini guna membangun hipotesis pengaruh antar variabel untuk digunakan pada riset selanjutnya. Hasilnya 1) Database berpengaruh terhadap Sistem Informasi Manajemen; 2) CCTV berpengaruh terhadap Sistem Informasi Manajemen; dan 3) Brainware berpengaruh terhadap Sistem Informasi Manajemen.
\end{abstract}

Keyword: sistem informasi manajemen, database, CCTV dan brainware

\section{INTRODUCTION}

\section{Latar Belakang Masalah}

Sistem informasi manajemen memainkan peran strategis dalam persaingan bebas saat ini. Integrasi sistem informasi dan teknologi informasi dengan komponen lain seperti proses, prosedur, sumber daya manusia, manajemen dan komponen terkait untuk menciptakan sistem informasi manajemen yang andal, merupakan salah satu kunci keberhasilan perusahaan.

Sistem informasi manajemen adalah unit komponen yang saling berhubungan yang mengumpulkan, memproses, menyimpan, dan mendistribusikan informasi untuk mendukung pengambilan keputusan dan manajemen dalam suatu perusahaan. Sistem informasi juga membantu manajer menyelidiki masalah, memvisualisasikan masalah yang kompleks, dan menghasilkan informasi yang akurat. Sistem informasi juga mencakup input, model, proses, output, penyimpanan, dan kontrol. Menggunakan sistem informasi untuk merencanakan, memproses, mengontrol, dan menggabungkan data untuk menentukan keberhasilan 
perusahaan. Secara umum, suatu sistem terdiri dari elemen-elemen yang saling berhubungan membentuk satu kesatuan yang memenuhi tujuan utama dari sistem tersebut.

Tujuan utama sistem komputer adalah mengolah data untuk menghasilkan informasi yang harus didukung oleh elemen perangkat keras, perangkat lunak, dan brainware. Perangkat keras adalah perangkat komputer itu sendiri, perangkat lunak adalah program yang berisi perintah untuk melakukan berbagai operasi, dan brainware adalah manusia yang terlibat dalam pengoperasian dan pengelolaan sistem komputer. Ketiga elemen sistem komputer tersebut harus saling berhubungan dan membentuk satu kesatuan. Jika perangkat kerjas tanpa perangkat lunak maka tidak ada yang dapat melakukan apa pun selain objek anonim. Perangkat keras dan perangkat lunak mungkin tidak berfungsi, tetapi tidak ada yang menjalankannya. Data sebagai sumber daya dalam suatu perusahaan perlu dikelola dengan baik, pengelolaan data yang terkomputerisasi menekankan pentingnya pengelolaan database dan pengelolaan sistem informasi serta aplikasinya. Makalah ini memberikan tinjauan literatur tentang determinasi sistem informasi manajemen: database, CCTV dan brainware.

\section{Rumusan Masalah}

Berdasarkan latar belakang, maka dapat di rumuskan permasalahan yang akan dibahas guna membangun hipotesis untuk riset selanjutnya yaitu:

1. Apakah database berpengaruh terhadap sistem informasi manajemen ?.

2. Apakah CCTV berpengaruh terhadap sistem informasi manajemen ?.

3. Apakah brainware berpengaruh terhadap sistem informasi manajemen ?.

\section{KAJIAN TEORI}

\section{Sistem Informasi Manajemen}

Entitas memiliki hubungan input yang memproses dan mengungkapkan informasi yang berguna untuk pengambilan keputusan dan pemantauan di kemudian hari. Pasti ada keterkaitan antar pekerjaan di masing-masing departemen perusahaan, jika pengelolaan di perusahaan masih diatur secara manual tanpa menggunakan sistem informasi, maka dapat dikatakan pekerjaan staf karyawan di departemen ini tidak efektif. Karena dengan berkembangnya waktu, hal-hal yang secara teknis dimungkinkan dalam jangka waktu yang lebih lama semua dimungkinkan oleh teknologi. Sistem informasi dapat dipahami sebagai alat bantu bagi pengguna untuk menyelesaikan pekerjaannya secara akurat, efisien dan efektif.

Menurut (Sholeh \& Wahyudin, 2021) sistem informasi manajemen adalah proses komunikasi di mana informasi dimasukkan, dicatat, disimpan, dan diambil untuk keputusan perencanaan, operasional, dan pemantauan. Sedangkan menurut (Sinaga et al., 2020) sistem informasi manajemen adalah suatu sistem yang terdiri dari sekumpulan bagian-bagian terstruktur yang bekerja sama untuk menghasilkan informasi untuk digunakan dalam manajemen bisnis. Menurut (Hakim, 2019), Sistem Informasi Manajemen (SIM) adalah sebuah mesin atau sistem manusia yang menyediakan informasi untuk mendukung aktivitas manajemen dan fungsi pengambilan keputusan dalam sebuah perusahaan. Sistem informasi 
manajemen juga dapat didefinisikan sebagai manajemen dalam mengumpulkan data dan menyajikan informasi yang mendasari keputusan perusahaan.

Menurut (Sholeh \& Wahyudin, 2021) indikator sistem informasi manajemen adalah: (1) akurasi, informasi harus benar, (2) informasi harus tepat waktu, pada saat dibutuhkan, (3) tepat bila sesuai, informasi yang diberikan harus sesuai dengan yang diminta (4) Lengkap, artinya informasi yang diberikan harus lengkap, artinya pengguna dapat menerima informasi yang menyajikan gambaran lengkap dari suatu masalah tertentu.

Menurut (Simanullang, 2021) berikut beberapa dasar penting sistem informasi manajemen sebagai berikut:

a) Hardware, perangkat fisik yang dapat digunakan untuk mengumpulkan, memasukkan, mengolah, menyimpan dan mempublikasikan hasil pengolahan data sebagai informasi.

b) Software, kumpulan program komputer yang digunakan untuk menjalankan komputer atau aplikasi tertentu pada komputer.

c) Brainware, merupakan komponen terpenting dari sumber daya manusia atau komponen dari sistem informasi manajemen itu sendiri.

d) Prosedur, melakukan serangkaian operasi yang dilakukan berulang-ulang dengan cara yang sama.

e) Basis data, dapat didefinisikan sebagai kumpulan data terkait untuk memudahkan proses pencarian informasi.

f) Komunikasi data dan jaringan komputer.

Menurut (Ali, 2009), tujuan penerapan sistem informasi manajemen pada dasarnya adalah untuk memberikan informasi kepada manajer/pimpinan tentang kinerja organisasi di masa lalu dan sekarang, dan lingkungannya serta proyeksinya untuk masa depan. Fungsi sistem informasi adalah mengumpulkan data, mengolah data dan informasi, menyimpan data informasi, dan mengirimkan informasi kepada manajer/pimpinan. Singkatnya, tujuan sistem informasi manajemen umumnya untuk memenuhi kebutuhan semua pihak manajemen mengenai ketersediaan informasi di dalam perusahaan atau di dalam unit organisasinya seperti alat pengambilan keputusan dan kebijakan perusahaan. Sistem Informasi Manajemen sudah banyak di teliti oleh peneliti sebelumnya diantaranya adalah:

\section{Database}

Menurut (Andaru, 2018) database adalah kumpulan informasi yang disimpan secara sistematis di dalam komputer sehingga dapat dikendalikan oleh program komputer untuk mengambil informasi dari database. Istilah "basis data" berasal dari ilmu komputer. Artikel ini adalah tentang database komputer, meskipun pentingnya kemudian diperluas untuk memasukkan hal-hal selain elektronik. Catatan seperti database ada sebelum Revolusi Industri dalam bentuk buku, kuitansi, dan kumpulan data bisnis.

Menurut (Yanti et al., 2018), database adalah suatu susunan atau kumpulan catatan data yang tersimpan di dalam komputer. Hubungan antar entri dalam database dapat digunakan sebagai sumber informasi bagi pengguna. Sampai saat ini, masih banyak record 
database yang ditampilkan dalam bentuk teks sebagai informasi kepada pengguna. Ini adalah salah satu kerentanan yang dimiliki analis kriptografi dalam mengakses, memanipulasi atau membocorkan dan mendistribusikan catatan basis data. Menurut (Melisa et al., 2014), database adalah kumpulan data dan deskripsi yang terhubung secara logis yang digunakan bersama dan dirancang untuk memenuhi kebutuhan informasi di suatu area.tempat tertentu.

Pada sistem informasi ini tiga komponen ini akan saling berkeja sama untuk membuat atau menginput data (Simanullang, 2021), yaitu:

a. Proses input data yang dimana merupakan kegiatan perpindahan atau memindahkan data untuk masuk ke sistem yang ada pada komputer agar data bisa digunakan dan disimpan melalui pengimpanan yang akan kita muat dalam bentuk file.

b. Pemprosesan data merupakan proses pengolahan yang akan dimuat dalam bentuk informasi.

c. Proses menghasilkan output berupa produk informasi dan sekumpulan data yang dikelola menjadi nilai yang menghasilkan infomasi.

Menurut (Lailela \& Kusumadiarti, 2018) bahwa perangkat lunak memiliki dimensi / indikator yaitu sebagai berikut:

a. Functionality (Fungsionalitas)

b. Indikator terdiri sebagai berikut: a) suitability (kesusaian), b) accuracy (keakuratan), c) security (keamanan), d) interoperability, dan e) compliance.

c. Reliability (Kehandalan)

d. Indikator terdiri sebagai berikut: a) maturity, b) fault tolerance (toleransi kesalahan) dan c) recoverability.

e. Usability (Kebergunaan)

f. Indikator terdiri sebagai berikut: a) understandability (kemudahan untuk dimengerti), b) learnability (kemudahan untuk dipelajari), c) operability (kemudahan untuk dioperasikan dan d) attractiveness.

g. Efficiency (Efisiensi)

h. Indikator terdiri sebagai berikut: a) time behavior dan b) resource behavior.

i. Maintainability (Pemeliharaan)

j. Indikator terdiri sebagai berikut: a) analyzability, b) changeability, c) stability dan d) testability.

k. Portability (Portabilitas)

1. Indikator terdiri sebagai berikut: a) adaptability, b) instability, c) coexistence dan d) replaceability.

\section{CCTV}

Sistem pelacakan itu penting. Pencurian, vandalisme, dll. Jika suatu peristiwa terjadi di daerah yang tidak memiliki sistem pengawasan, maka tidak ada dokumentasi peristiwa tersebut. Sistem surveilans juga dapat mencegah terjadinya insiden karena secara psikologis pelaku insiden akan berubah pikiran dua kali dan akan melakukan hal tersebut di wilayah 
yang sudah diatur dengan sistem surveilans. Salah satu alat untuk mendukung sistem pengawasan adalah CCTV (Closed Circuit Television).

Menurut (Sari, 2021), CCTV adalah kamera video digital yang memonitor dan mentransmisikan sinyal video dalam suatu ruangan, kemudian mentransmisikan sinyal tersebut ke layar kendali. Ada beberapa kriteria untuk menempatkan kamera CCTV, seperti posisi, target, cahaya dan permukaan. Sedangkan menurut (Pratomo et al., 2018), terdapat sistem pengawasan CCTV dengan kamera video yang menampilkan dan merekam gambar di tempat dan waktu peralatan dipasang. CCTV menggunakan sinyal rahasia atau terselubung yang merupakan sinyal siaran, berbeda dengan televisi biasa pada umumnya. Menurut (Astra \& Mardiana, 2018), CCTV (Closed Circuit Television) adalah perangkat kamera video digital yang digunakan untuk mengirim sinyal ke layar kontrol di ruangan atau lokasi tertentu. Tujuannya adalah untuk memantau kondisi dan kondisi suatu tempat tertentu.

CCTV ini berfungsi sebagai alat pengambil gambar, ada banyak jenis kamera yang berbeda dari segi kualitas, penggunaan dan fungsi, dua jenis utama adalah kamera CCTV analog dan kamera jaringan CCTV dimana kamera analog menggunakan kabel tunggal. . Saat menghubungkan ke DVR atau sistem, kamera jaringan atau yang biasa dikenal dengan kamera IP dapat menggunakan jaringan, yaitu jaringan paralel dan bercabang dan menghemat waktu pemasangan karena tidak ada kabel khusus untuk setiap akses ke kamera. DVR (Perekam Video Digital). CCTV merupakan sebuah sistem yang menggunakan kamera untuk merekam semua gambar yang dikirim oleh kamera pada sistem ini, terdapat banyak fitur yang dapat kita gunakan untuk mendukung keamanan salah satunya adalah merekam semua kejadian dan hasil penulisan ini banyak digunakan. Untuk membuktikan fakta ini, pengadilan menentukan kuantitas dan kualitas rekaman DVR ini.

Elemen-elemen CCTV (Closed Circuit Television) berikut: Keberhasilan sistem CCTV ditentukan oleh kualitas elemen-elemen yang mendukung sistem tersebut diantaranya adalah:

a. Kamera: Berdasarkan kategori bentuk terbagi menjadidua macam yaitu fixed camera (Posisi Kamera tidak bisa berubah ubah) dan PTZ (Pan Tilt Zoom) camera (Posisi Kamera dapat berubah dan dapat di zoom).

b. Media Transmisi: Media transmisi dari CCTV menggunakan kabel koaksial atau UTP sedangkan wireless menggunakan acces point berupa Router.

c. Monitor: menampilkan objek yang ditangkap oleh kamera.

d. Aplikasi piranti lunak: suatu aplikasi yang dapat mengontrol CCTV dari suatu tempat dan dapat diintergrasikan dengan server penyimpanan video.

e. Media Penyimpanan: DVR (Digital Video Recorder) atau Hardisk.

\section{Brainware}

Sistem informasi manajemen merupakan bagian dari pengendalian internal perusahaan, termasuk penggunaan sumber daya manusia, dokumen, teknologi, dan prosedur manajemen untuk memecahkan masalah bisnis. Istilah yang umum dikenal, sistem informasi 
manajemen adalah sistem terintegrasi yang menyediakan informasi tentang seseorang/mesin untuk mendukung fungsi operasional, manajemen, dan pengambilan keputusan dalam suatu perusahaan. Sistem ini menggunakan perangkat keras dan perangkat lunak komputer, proses manajemen, model manajemen dan pengambilan keputusan, dan "basis data".

Sementara itu (Alfriza Frisdayanti, 2019) Menurut Brainware, ada satu orang yang memiliki, memasang, dan mengoperasikan sistem informasi manajemen. Konsep orang di sini bukan hanya seseorang dalam arti manusia, tetapi orang yang memiliki kemampuan (pengetahuan dan keterampilan atau keahlian). Menurut Azhar Susanto et al (Mintarsih et al., 2018), brainware adalah sumber daya yang berkaitan dengan pembuatan sistem informasi, pengumpulan dan pemrosesan data, serta distribusi dan penggunaan informasi yang dihasilkan oleh sistem.sistem informasi yang dihasilkan.

Menurut (Mintarsih et al., 2018) umumnya brainware sebagai sumber daya manusia pada saat sistem informasi dikembangkan dapat dibagi kedalam empat kelompok, yaitu:

a. Pemiliki, yang memberikan dukungan dana sampai dengan waktu saat mengembangkan.

b. Pemakai, yang menggunakan sistem informasi yang telah dikembangkan seperti operator dan manajer (end user).

c. Perancang, yang merancang sistem informasi.

d. Pembangun (builder), yang membangun sistem informasi.

Tabel 1: Penelitian terdahulu

\begin{tabular}{|c|c|c|c|c|}
\hline No & Author (tahun) & Hasil Riset terdahulu & $\begin{array}{l}\text { Persamaan dengan } \\
\text { artikel ini }\end{array}$ & $\begin{array}{l}\text { Perbedaan dengan } \\
\text { artikel ini }\end{array}$ \\
\hline 1 & $\begin{array}{l}\text { (Alfriza } \\
\text { Frisdayanti, } \\
\text { 2019) }\end{array}$ & $\begin{array}{l}\text { Peranan brainware dalam } \\
\text { sistem informasi } \\
\text { manajemen }\end{array}$ & $\begin{array}{l}\text { Brainware berpengaruh } \\
\text { terhadap sistem } \\
\text { informasi manajemen }\end{array}$ & $\begin{array}{l}\text { Informasi dan sistem } \\
\text { informasi berpengaruh } \\
\text { terhadap sistem } \\
\text { informasi manajemen }\end{array}$ \\
\hline 2 & (Andaru, 2018) & $\begin{array}{l}\text { Pengertian database secara } \\
\text { umum }\end{array}$ & $\begin{array}{l}\text { Database berpengaruh } \\
\text { terhadap sistem } \\
\text { informasi manajemen }\end{array}$ & $\begin{array}{l}\text { Database berpengaruh } \\
\text { terhadap sistem } \\
\text { informasi manajemen }\end{array}$ \\
\hline 3 & $\begin{array}{l}\text { (Astra \& } \\
\text { Mardiana, 2018) }\end{array}$ & $\begin{array}{l}\text { Rancang bangun dan } \\
\text { analisa pengendali CCTV } \\
\text { berbasis Arduino } \\
\text { menggunakan smartphone } \\
\text { android }\end{array}$ & $\begin{array}{l}\text { Pengendali CCTV } \\
\text { berpengaruh terhadap } \\
\text { sistem informasi } \\
\text { manajemen }\end{array}$ & $\begin{array}{l}\text { Bluetooth berpengaruh } \\
\text { terhadap sistem } \\
\text { informasi manajemen }\end{array}$ \\
\hline 4 & $\begin{array}{l}\text { (Astuti et al., } \\
2015 \text { ) }\end{array}$ & $\begin{array}{l}\text { Konsep dan peranan sistem } \\
\text { database di dalam sistem } \\
\text { informasi manajemen }\end{array}$ & $\begin{array}{l}\text { Sistem database } \\
\text { berpengaruh terhadap } \\
\text { sistem informasi } \\
\text { manajemen }\end{array}$ & $\begin{array}{l}\text { Peranan sistem } \\
\text { database berpengaruh } \\
\text { terhadap sistem } \\
\text { informasi manajemen }\end{array}$ \\
\hline 5 & (Bate'e, 2021) & $\begin{array}{l}\text { Analisis sistem informasi } \\
\text { manajemen dalam } \\
\text { penanganan gangguan } \\
\text { keamanan bandara }\end{array}$ & $\begin{array}{l}\text { CCTV berpengaruh } \\
\text { terhadap sistem } \\
\text { informasi manajemen }\end{array}$ & $\begin{array}{l}\text { Aviation security } \\
\text { bandara berpengaruh } \\
\text { terhadap sistem } \\
\text { informasi manajemen }\end{array}$ \\
\hline 6 & $\begin{array}{l}\text { (Lailela \& } \\
\text { Kusumadiarti, }\end{array}$ & $\begin{array}{l}\text { Pengukuran kualitas } \\
\text { perangkat lunak aplikasi }\end{array}$ & $\begin{array}{l}\text { Perangkat lunak } \\
\text { berpengaruh terhadap }\end{array}$ & $\begin{array}{l}\text { Pengukuran kualitas, } \\
\text { aplikasi, ISO } 9126 \text { dan }\end{array}$ \\
\hline
\end{tabular}




\begin{tabular}{|c|c|c|c|c|}
\hline & 2018) & $\begin{array}{l}\text { SISFO_Nilai di poleteknik } \\
\text { piksi ganesha berdasarakan } \\
\text { ISO } 9126\end{array}$ & $\begin{array}{l}\text { sistem informasi } \\
\text { manajemen }\end{array}$ & $\begin{array}{l}\text { SISFO_Nilai terhadap } \\
\text { sistem informasi } \\
\text { manajemen }\end{array}$ \\
\hline 7 & $\begin{array}{l}\text { (Melisa et al., } \\
\text { 2014) }\end{array}$ & $\begin{array}{l}\text { Penerapan metode SAW } \\
\text { dalam sistem pendukung } \\
\text { keputusan pemilihan } \\
\text { jurusan pada Sekolah } \\
\text { Menengah Atas Negeri } 8 \\
\text { Seluma }\end{array}$ & $\begin{array}{l}\text { Database berpengaruh } \\
\text { terhadap sistem } \\
\text { informasi manajemen }\end{array}$ & $\begin{array}{l}\text { Metode simple } \\
\text { additive weighting } \\
\text { (SAW) berpengaruh } \\
\text { terhadap Sistem } \\
\text { pendukung }\end{array}$ \\
\hline 8 & $\begin{array}{l}\text { (Mintarsih et al., } \\
\text { 2018) }\end{array}$ & $\begin{array}{l}\text { Kompetensi brainware } \\
\text { dalam eksistensi sistem } \\
\text { informasi open library }\end{array}$ & $\begin{array}{l}\text { Brainware berpengaruh } \\
\text { terhadap sistem } \\
\text { informasi }\end{array}$ & $\begin{array}{l}\text { Kompetensi } \\
\text { pustakawan, layanan } \\
\text { sirkulasi dan open } \\
\text { libray berpengaruh } \\
\text { terhadap sistem } \\
\text { informasi }\end{array}$ \\
\hline 9 & $\begin{array}{l}\text { (Pratomo et al., } \\
\text { 2018) }\end{array}$ & $\begin{array}{l}\text { Evaluasi jaringan closed } \\
\text { circuit television (CCTV) } \\
\text { di Insitut Teknologi } \\
\text { Sepuluh Nopember (ITS) }\end{array}$ & $\begin{array}{l}\text { CCTV berpengaruh } \\
\text { terhadap sistem } \\
\text { informasi }\end{array}$ & $\begin{array}{l}\text { Pemetaan, pengukuran } \\
\text { dan WEMITS } \\
\text { berpengaruh terhadap } \\
\text { sistem informasi }\end{array}$ \\
\hline 10 & (Sari, 2021) & $\begin{array}{l}\text { Sistem pendukung } \\
\text { keputusan penentuan loasi } \\
\text { pemasangan CCTV } \\
\text { dengan Metode MOORA } \\
\text { (Studi Kasus : Dinas } \\
\text { Perhubungan Kota Binjai) }\end{array}$ & $\begin{array}{l}\text { CCTV berpengaruh } \\
\text { terhadap sistem } \\
\text { informasi manajemen }\end{array}$ & $\begin{array}{l}\text { MOORA dan lokasi } \\
\text { berpengaruh terhadap } \\
\text { sistem informasi } \\
\text { manajemen }\end{array}$ \\
\hline 11 & $\begin{array}{l}\text { (Sholeh \& } \\
\text { Wahyudin, 2021) }\end{array}$ & $\begin{array}{l}\text { Pengaruh sistem informasi } \\
\text { manajemen dan } \\
\text { kompetensi terhadap } \\
\text { efektivitas kerja di PT } \\
\text { Citra Solusi Informatika }\end{array}$ & $\begin{array}{l}\text { Sistem informasi } \\
\text { manajemen } \\
\text { berpengaruh terhadap } \\
\text { efektivitas kerja }\end{array}$ & $\begin{array}{l}\text { Kompetensi kerja } \\
\text { berpengaruh terhadap } \\
\text { efektivitas kerja }\end{array}$ \\
\hline 12 & $\begin{array}{l}\text { (Simanullang, } \\
\text { 2021) }\end{array}$ & $\begin{array}{l}\text { Pengaruh perangkat keras } \\
\text { komputer dalam sistem } \\
\text { informasi manajemen }\end{array}$ & $\begin{array}{l}\text { Perangkat keras } \\
\text { komputer berpengaruh } \\
\text { terhadap sistem } \\
\text { informasi manajemen }\end{array}$ & $\begin{array}{l}\text { Sistem informasi dan } \\
\text { informasi berpengaruh } \\
\text { terhadap sistem } \\
\text { informasi manajemen }\end{array}$ \\
\hline 13 & $\begin{array}{l}\text { (Sinaga et al., } \\
\text { 2020) }\end{array}$ & $\begin{array}{l}\text { Pengaruh motivasi kerja } \\
\text { dan sistem informasi } \\
\text { manajemen terhadap } \\
\text { kinerja pegawai pada BPJS } \\
\text { (Badan Penyelenggara } \\
\text { Jaminan Sosial) } \\
\text { Ketenagakerjaan Cabang } \\
\text { Meda }\end{array}$ & $\begin{array}{l}\text { Sistem informasi } \\
\text { manajemen } \\
\text { berpengaruh terhadap } \\
\text { kinerja pegawai }\end{array}$ & $\begin{array}{l}\text { Motivasi kerja } \\
\text { berpengaruh terhadap } \\
\text { kinerja kerja pegawai }\end{array}$ \\
\hline 14 & $\begin{array}{l}\text { (Yanti et al., } \\
\text { 2018) }\end{array}$ & $\begin{array}{l}\text { Implementasi algoritma } \\
\text { data encryption standard } \\
\text { pada penyandian record } \\
\text { database }\end{array}$ & $\begin{array}{l}\text { Database berpengaruh } \\
\text { terhadap sistem } \\
\text { informasi manajemen }\end{array}$ & $\begin{array}{l}\text { Kriptogradi, DES dan } \\
\text { record berpengaruh } \\
\text { terhadap sistem } \\
\text { informasi manajemen }\end{array}$ \\
\hline
\end{tabular}

\section{METODE PENELITIAN}

Metode penulisan artikel ilmiah ini adalah dengan metode kualitatif dan kajian pustaka (Library Research). Mengkaji teori dan hubungan atau pengaruh antar variabel dari 
buku-buku dan jurnal baik secara off line di perpustakaan dan secara online yang bersumber dari Mendeley, Scholar Google dan media online lainnya.

Dalam penelitian kualitatif, kajian pustaka harus digunakan secara konsisten dengan asumsi-asumsi metodologis. Artinya harus digunakan secara induktif sehingga tidak mengarahkan pertanyaan-pertanyaan yang diajukan oleh peneliti. Salah satu alasan utama untuk melakukan penelitian kualitatif yaitu bahwa penelitian tersebut bersifat eksploratif, (Ali \& Limakrisna, 2013).

\section{HASIL DAN PEMBAHASAN}

Dalam pembahasan artikel ini difokuskan pada upaya untuk menganalisis dan membahas beberapa variabel yang berkaitan dengan Sistem Informasi Manajemen (SIM) yaitu diantaranya: Database, CCTV, Brainware dan Sistem Informasi Manajemen berdasarakan study literature terdahulu yang dianggap relevan yaitu:

\section{Pengaruh Database terhadap Sistem Informasi Manajemen}

Menurut (Astuti et al., 2015), sistem basis data memiliki komponen-komponen penting, seperti database, yang merupakan tulang punggung sistem basis data. Software yang digunakan untuk mengolah database dan hardware yang digunakan untuk mendukung pengolahan data dan personalia. Sistem database sangat berperan penting dalam sistem informasi manajemen dimana sistem database berperan sebagai komponen sistem informasi manajemen, infrastruktur sistem informasi manajemen, sumber informasi sistem informasi manajemen, sarana untuk efisiensi sistem informasi manajemen, dan sarana untuk efektivitas sistem informasi manajemen. Variabel database dan sistem informasi manajemen sudah banyak di teliti oleh peneliti sebelumnya di antaranya adalah x1: Database dan y: Sistem Informasi Manajemen.

\section{Pengaruh CCTV terhadap Sistem Informasi Manajemen}

CCTV merupakan suatu alat dengan fungsi instrument yang dapat merekam keadaan lingkungan. Oleh karena itu memiliki keunggulan seperti barang bukti, pengawasan dalam bekerja dan sangat efektif dalam sistem informasi manajemen perusahaan. Menurut (Bate, 2021), sistem informasi manajemen dapat memberikan dukungan informasi dalam proses pengambilan keputusan dan merupakan penentu program kerja seperti sumber biaya, lokasi pelaksanaan, sistem pelaporan penilaian dan keuntungan yang akan diperoleh. Oleh karena itu, CCTV memiliki hubungan yang erat dengan sistem informasi manajemen sebagai contoh perusahaan AIRIN Logistik EMKL/EMKU yang memiliki fasilitas penyimpanan/gudang. Bagian SK3LH perusahaan memiliki lokasi TPS (Tempat Penyimpanan Sementara) dengan CCTV untuk pemantauan dan pengawasan. Sehingga sistem informasi manajemen perusahaan bekerja sesuai dengan program kerja yang telah direncanakan. Variabel x 2 dan y sudah banyak di teliti oleh peneliti sebelumnya di antaranya adalah x2: CCTV, dan y: Sistem Informasi Manajemen.

\section{Pengaruh Brainware terhadap Sistem Informasi Manajemen}

Sistem informasi manajemen sangat bergantung pada komponen-komponen yang membentuk sistem informasi untuk memenuhi kebutuhannya. Kesenjangan dalam 
implementasi komponen-komponen tersebut akan mengakibatkan informasi yang kurang akurat, kurang detail, kurang tepat waktunya dan kurang relevan. Sehingga menimbulkan kesalahan dalam pengambilan keputusan perusahaan. Oleh karena itu, diperlukan pemahaman yang mendalam tentang komponen dan sistem informasi manajemen, terutama brainware, untuk menghasilkan informasi yang dapat digunakan oleh perusahaan untuk mendapatkan sustainable competitive advantages. Sistem informasi manajemen bergantung pada komponen yang membentuk sistem informasi untuk memenuhi kebutuhan mereka. Kesenjangan dalam implementasi komponen ini akan menyebabkan informasi yang kurang akurat, kurang detail, kurang akurat dan kurang tepat waktu sehingga dapat menyebabkan kesalahan dalam pengambilan keputusan perusahaan. Variabel x3 dan y sudah banyak di teliti oleh peneliti sebelumnya di antaranya adalah x3: Brainware, dan y: Sistem Informasi Manajemen.

\section{Conceptual Framework}

Berdasarkan rumusan masalah penulisan artikel ini dan kajian studi literature review baik dari buku dan artikel yang relevan, maka di perolah rerangka artikel ini seperti di bawah ini.

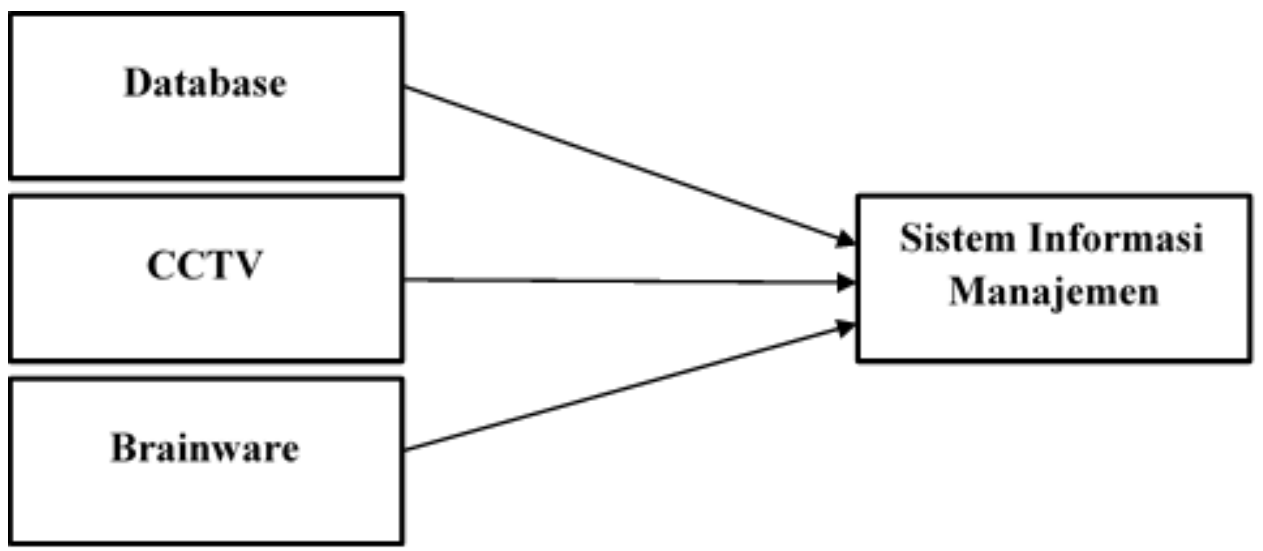

Figure 1: Conceptual Framework

Berdasarkan Kajian teori dan review hasil dari artikel yang relevan serta gambar dari conceptual framework, maka: Database, CCTV, dan Brainware berpengaruh terhadap Sistem Informasi Manajemen. Selain dari tiga variabel exogen ini yang mempengaruhi y, masih banyak variabel lain yang mempengaruhinya diantaranya adalah:

a) Informasi: (Oscar, 2018), (Yesi, 2018)

b) Lokasi: Farah 2018), (Tina, 2018), dan (Mahmudin, 2018).

c) Internet: (Neti, 2018), (Alimah, 2018), dan (Desi, 2018).

\section{KESIMPULAN DAN SARAN}

\section{Kesimpulan}

Berdasarkan teori, artikel yang relevan dan pembahasan maka dapat di rumuskan hipotesis untuk riset selanjutnya: 
1. Database berpengaruh terhadap Sistem Informasi Manajemen.

2. CCTV berpengaruh terhadap Sistem Informasi Manajemen.

3. Brainware berpengaruh terhadap Sistem Informasi Manajemen.

\section{Saran}

Berdasarkan kesimpulan di atas, maka saran pada artikel ini adalah bahwa masih banyak faktor lain yang mempengaruhi sistem informasi manajemen, selain dari database, CCTV, dan brainware pada semua tipe dan tingkat perusahaan. Oleh karena itu masih di perlukan kajian yang lebih lanjut untuk mencari faktor-faktor lain apa saja yang dapat mempengaruhi sistem informasi manajemen selain yang varibel yang di teliti pada arikel ini. Faktor lain tersebut seperti jaringan, internet, kepuasaan penggunaan dan lokasi pemetaan.

\section{DAFTAR RUJUKAN}

Alfriza Frisdayanti. (2019). Peranan brainware dalam sistem informasi manajemen jurnal ekonomi dan manajemen sistem informasi. Jurnal Ekonomi Dan Manajemen Sistem Informasi, 1(September), 60-69. https://doi.org/10.31933/JEMSI

Ali, H., Limakrisna, N., \& Jamaluddin, S. (2016). Model of customer satisfaction: The empirical study at Bri in Jambi. International Journal of Applied Business and Economic Research.

Ali, H. (2009). Sistem Informasi Manajemen Berbasis Teknologi Informasi. 199.

Andaru, A. (2018). Pengertian database secara umum. OSF Preprints, 2.

Astra, O. A., \& Mardiana, Y. (2018). Rancang Bangun dan Analisa Pengendali CCTV Berbasis Arduino Menggunakan Smartphone Android. Jurnal Media Infotama, 14(1). https://doi.org/10.37676/jmi.v14i1.470

Astuti, S. I., Arso, S. P., \& Wigati, P. A. (2015). 済無No Title No Title No Title. Analisis Standar Pelayanan Minimal Pada Instalasi Rawat Jalan Di RSUD Kota Semarang, 3, 103-111.

Bate'e, M. M. (2021). Analisis Sistem informasi Manajemen dalam Penanganan Gangguan Keamanan Bandara. Jesya (Jurnal Ekonomi \& Ekonomi Syariah), 4(2), 1034-1044. https://doi.org/10.36778/jesya.v4i2.480

Hakim, L. (2019). Prinsip-Prinsip Dasar Sistem Informasi Manajemen: Dilengkapi Teori Dasar Sistem Informasi Manajemen Pendidikan. In Timur Laut Aksara | ISBN : 978602-53849-2-9 (Issue i). http://repository.uinjambi.ac.id/390/1/FINAL MATERI BUKU SIM.pdf

Lailela, S. N., \& Kusumadiarti, R. S. (2018). 96-Article Text-97-3-10-20200702. 2(2).

Melisa, Elistri, Jusuf, Wahyudi, Reno, \& Supardi. (2014). Fuzzy Multi-Attribute Decision Making. Yogyakarta. Graha Ilmu. 10(2), 361. 
Mintarsih, T., . M., \& Ruqayah, F. (2018). Kompetensi Brainware Dalam Eksistensi Sistem Informasi Open Library. Nusantara - Journal of Information and Library Studies, 1(1), 103. https://doi.org/10.30999/n-jils.v1i1.275

Pratomo, I., Sakinah, S., \& Affandi, A. (2018). Evaluasi Jaringan Closed Circuit Television (CCTV) di Institut Teknologi Sepuluh Nopember (ITS). Applied Technology and Computing Science Journal, 1(2), 105-113. https://doi.org/10.33086/atcsj.v1i2.858

Sari, U. L. (2021). Sistem Pendukung Keputusan Penentuan Lokasi Pemasangan CCTV dengan Metode MOORA ( Studi Kasus : Dinas Perhubungan Kota Binjai).

Sholeh, M., \& Wahyudin, D. (2021). Pengaruh Sistem Informasi Manajemen Dan Kompetensi Terhadap Efektifitas Kerja Di Pt Citra Solusi Informatika. 3(1), 28-41. http://ojs.stiami.ac.id

Simanullang, P. M. (2021). Pengaruh perangkat keras komputer dalam sistem informasi manajemen.

Sinaga, D. S., Sinaga, J., \& ... (2020). ... Dan Sistem Informasi Manajemen Terhadap Kinerja Pegawai Pada Bpjs (Badan Penyelenggara Jaminan Sosial) Ketenagakerjaan .... Jurnal Global ..., 9, 11-19. http://jurnal.darmaagung.ac.id/index.php/global/article/view/601

Yanti, N. R., Alimah, A., \& Ritonga, D. A. (2018). Implementasi Algoritma Data Encryption Standard Pada Penyandian Record Database. J-SAKTI (Jurnal Sains Komputer Dan Informatika), 2(1), 23. https://doi.org/10.30645/j-sakti.v2i1.53 